Egyptian Journal of Rabbit Science, 27 (2): 485 - 506 (2017)

\title{
EFFECT OF ADDING OF ENZYME COMPLEX (KEMZYME) TO DIET CONTAINING DATE STONE MEAL ON BLOOD PARAMETERS, IMMUNE RESPONSE, MICROBIAL ACTIVITY AND CARCASS CHARACTERISTICS OF GROWING RABBITS.
}

\author{
M. I. El-Kelawy ${ }^{1}$ and A. S. El-Shafey ${ }^{2}$ \\ ${ }^{1}$ Department of Poultry Production, Faculty of Agriculture (New Valley), \\ Assiut University, Egypt. \\ ${ }^{2}$ Department of Animal and Poultry Production, Faculty of Agriculture, \\ Damanhour University, Egypt.
}

\section{ABSTRACT:}

This study aimed to evaluate impact of enzymes mixture (EZ) addition to diets containing date stones meal (DSM) on body weight, blood parameters, immune response and carcass characteristics of growing rabbits. Seventy-five New Zealand White (NZW) rabbits, 28 days of age with average weight $491 \pm 2.77 \mathrm{~g}$, were randomly divided into fiveexperimental groups. The $1^{\text {st }}$ group was fed control diet (Diet A) contained 0\% DSM and served as a control. The $2^{\text {nd }}, 3^{\text {rd }}$ groups, were fed diets contained $10 \%$ DSM either without (Diet B) or with EZ (1 g/ $K g$ diet) diet addition (Diet $C$ ), respectively. The $4^{\text {th }}$ and $5^{\text {th }}$ groups, were fed diets contained $20 \%$ DSM either without (Diet D) or with EZ $(1 \mathrm{~g} / \mathrm{Kg}$ diet) addition (Diet E), respectively. At the end of the experimental period five rabbits from each groupwere taken to determine carcass characteristics, blood parameters and meat quality.

Percentages of dressing were significantly $(P<0.05)$ higher in rabbits fed 10\% DSM+EZ than the other groups. The protein and lipid percentage of meat were significantly higher in rabbit fed $A, C$ and $E$ diets than those fed Diet D, the levels of glucose, total lipid, triglycerides, $H D L, L D L$ and $R B C$ 's were significantly $(P<0.05)$ higher, whereas GPX and SOD percentages were lower $(P<0.05)$ in rabbits fed $A$ or $C$ diets than the other groups. Higher values of $\alpha-$ globulin, BA and $L T T$ were recorded with rabbits fed $A, B$ or $C$ diets compared with other groups. IgA, IgM and IgG were significantly higher in rabbits fed $A, C$ or $E$ diets than the other groups. No significant differences were 
recorded in creatinine, AST, ALT, alkaline phosphates, cholesterol, total protein, albumin, TAC, GSH, globulin, globulin- $\gamma, L A, P I$ and PA, hematological criteria and differential leucocytes counts among the different groups. Total bacterial, Salmonella, E. Coli and Proteus bacterial counts were significantly lower in rabbits fed $B, C, D$ or $E$ diets than the control group.

In conclusion, date stones meal can be included in rabbit diets up to $10 \%$ with adding enzyme complex (Kemzyme) without any adverse effects on body weights, blood parameters, immune index, carcass characteristics and meat quality.

Keywords: Rabbits, enzymes, date stone meal, carcass characteristics, blood parameters.

The feed cost represents more than $70 \%$ of the total costs for rabbits production (El-Sayaad, 2002). Due to the constantly growing in the prices of main ingredients in poultry and rabbits feed as the results of feed shortage and in port most of the concentrated feed ingredients from abroad with foreign currency especially soybean meal and corn grains. Therefore, to decrease the cost of feeding, it is necessary to search about alternatives such as agricultural and industrial by-products (El-Manelawy and El-Banna, 2013).

Date stonesare produced in date industry in tremendous amounts in Egypt about 1.1 million tons are produced yearly (Gaber et al., 2012). The date stones are the inedible part of date, represents about $10 \%$ of the date's weight, and could be utilized as a feed source for animals (Al-Homidan 2003, Aldhaheri et al. 2004 and Zanu et al., 2012). The nutritive value of date stonesranged from $5.64 \%$ to $8.20 \%$ crude protein $(\mathrm{CP}), 1.60-9.35 \%$ ether extract(EE), 9.10-22.0\% crude fibre (CF), 58.5-75.4\% nitrogen free extract (NFE), 38.5-73.1 \%neutral detergent fiber (NDF), 17.2-35.3\% acid detergent fiber (ADF), 0.19-0.32\% methionine and cystine, and 0.19-0.30\% lysine. ME value ranges from 1,350 to $1,746 \mathrm{kcal} / \mathrm{kg}$ diet (Aldhaheri et al., 2004). Date stones are good source of antioxidants, mainly carotenoids and phenolics (Al-Farsi and Lee, 2008). There is a propensity to decline total bacteria and $E$. coli with feeding diets contain DSM (El-Deek et al., 2008 and Al-Harthi et al., 2009). The total bacterial counts in the jejunum contents showed a decrease when the date seeds were used. Date stone meal(DSM)was used in rabbit diets without adverse effect on rabbit performance (Soliman et al., 2009) and on protein digestion, liver and renal functions (Attia, and Al-Harthi, 2015). 
Some experiments showed positive effect of EZ addition in the rabbits diets. Ronaled (2007), found that rabbits diet supplementation with multienzymes mixture increase the haemoglobin and leukocyte level in the blood of the experimentalanimals. Abd El-Latif et al. (2008) revealed that EZ addition to rabbit diets improved the level of serum total protein, albumin, globulin, glucose, ALT, AST and total lipids. Multienzymes mixture supplementation in the diets led to a reduction in pathogens, total anaerobics, Gram-positive cocci, and enterococci in the intestine microbiota (Tabook et al., 2006).

The present study was carried out to investigate impact of enzymes mixture (EZ) addition to the diets containing date stones meal (DSM) on some blood parameters, immune index, carcass characteristics and meat quality of growing rabbits.

\section{MATERIALS AND METHODS}

The experimental work of this study was carried out at the Poultry Research Unit, Damanhour University, Egypt from December, 2016 to February, 2017.

Seventy-five New Zealand White rabbits (NZW), 28 days of age and approximately $491 \pm 2.77 \mathrm{~g}$ body weight, were randomly divided into five experimental groups (15 rabbits in each one). All rabbits were fed one of the experimental pelleted diets (Table 1 ). Rabbits of the $1^{\text {st }}$ group were fed control basal diet contained 0\% DSM. The $2^{\text {nd }}$ and $3^{\text {rd }}$ groups, were fed diets contained $10 \%$ DSM either without or with EZ $(1 \mathrm{~g} / \mathrm{Kg})$ addition, respectively. The $4^{\text {th }}$ and $5^{\text {th }}$ groups, were fed diets contained $20 \%$ DSM either without or with EZ (1g/ $\mathrm{Kg}$ ) addition, respectively. Enzyme complex (kemzyme) contained from $300 \mu / \mathrm{g}$ Beta-glucanase, $5000 \mu / \mathrm{g}$ cellulose, $450 \mu / \mathrm{g}$ Alfa amylase and $450 \mu / \mathrm{g}$ protase and lipase.

Date stones were obtained from El-Wadi El-Gaded Governorate and processed according to (Al-Harthi et al., 2009) by sun-drying for 72 hours and ground in a heavy-duty high rotation hammer mill to pass through $1 \mathrm{~mm}$. mesh sieve, producing a fine powder suitable for chemical analysis before mixing to the diets. The diets, DSM, barley and wheat bran samples were chemically analyzed for determination of dry matter (DM), crude protein (CP), ether extract (EE), crude fibre (CF), ash and nitrogen free extract (NFE) according to AOAC (2004) as shown in Table 2. 
Table (1): Ingredients and chemical analysis of the experimental diets.

\begin{tabular}{|c|c|c|c|c|c|}
\hline \multirow{2}{*}{ Ingredients } & \multicolumn{5}{|c|}{ Experimental diets (\%) } \\
\hline & $\begin{array}{l}\text { Control } \\
\text { (Diet A) }\end{array}$ & $\begin{array}{c}\text { 10\% DSM } \\
\text { (Diet B) }\end{array}$ & $\begin{array}{c}\text { 10\% DSM } \\
\text { (Diet C) }\end{array}$ & $\begin{array}{c}\text { 20\% DSM } \\
\text { (Diet D) }\end{array}$ & $\begin{array}{c}\text { 20\% DSM } \\
\text { (Diet E) }\end{array}$ \\
\hline Yellow Corn & 11.22 & 11.22 & 11.22 & 11.22 & 11.22 \\
\hline Barley & 15.00 & 10.00 & 10.00 & 10.00 & 10.00 \\
\hline Wheat bran & 23.33 & 18.33 & 18.30 & 8.33 & 8.30 \\
\hline Alfalfa hay & 30.12 & 30.12 & 30.10 & 30.12 & 30.10 \\
\hline Soya bean meal & 17.33 & 17.33 & 17.33 & 17.33 & 17.33 \\
\hline Data stone meal & 0.00 & 10.00 & 10.00 & 20.00 & 20.00 \\
\hline Vit. + Min. Premix ${ }^{*}$ & 0.30 & 0.30 & 0.30 & 0.30 & 0.30 \\
\hline Salt $(\mathrm{NaCl})$ & 0.50 & 0.50 & 0.50 & 0.50 & 0.50 \\
\hline Dicalcium Phosphate & 1.20 & 1.20 & 1.20 & 1.20 & 1.20 \\
\hline Lime stone & 1.00 & 1.00 & 1.00 & 1.00 & 1.00 \\
\hline Enzyme & 0.00 & 0.00 & 0.05 & 0.00 & 0.05 \\
\hline Total & 100.00 & 100.00 & 100.00 & 100.00 & 100.00 \\
\hline \multicolumn{6}{|l|}{ Chemical analysis } \\
\hline Dry matter & 87.63 & 87.18 & 87.08 & 87.53 & 87.53 \\
\hline Ash & 6.27 & 6.54 & 6.57 & 6.33 & 6.30 \\
\hline Crude protein & 17.69 & 17.31 & 17.36 & 16.87 & 16.75 \\
\hline Crude fat & 2.91 & 3.09 & 3.13 & 3.55 & 3.58 \\
\hline Crude fiber & 12.78 & 13.25 & 13.22 & 14.07 & 14.00 \\
\hline NDF & 37.02 & 37.73 & 37.73 & 38.29 & 38.28 \\
\hline $\mathrm{ADF}$ & 20.67 & 21.65 & 21.65 & 22.43 & 22.42 \\
\hline Hemicellulose & 16.35 & 16.08 & 16.08 & 15.86 & 15.86 \\
\hline Digestible energy & 2542 & 2508 & 2508 & 2480 & 2480 \\
\hline \multicolumn{6}{|c|}{ 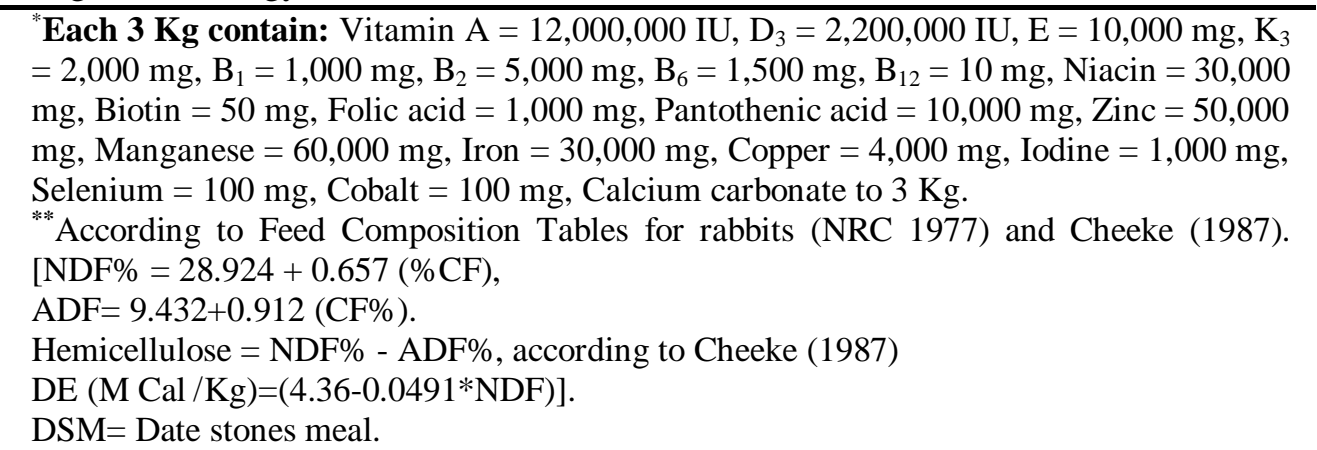 } \\
\hline
\end{tabular}


EFFECTOFADDINGOFKEMZYMETODIETCONTAININGDATESTONEMEALONRABBITS. 489

Table (2). The chemical analysis of the date stone, barley and wheat bran.

\begin{tabular}{lcllllc}
\hline Composition & Moisture & $\begin{array}{l}\text { Crude } \\
\text { protein }\end{array}$ & $\begin{array}{l}\text { Ether } \\
\text { extract }\end{array}$ & $\begin{array}{c}\text { Crude } \\
\text { fiber }\end{array}$ & Ash & $\begin{array}{c}\text { Nitrogen free } \\
\text { extract }\end{array}$ \\
\hline DSM & 8.23 & 6.38 & 7.41 & 17.94 & 1.42 & 58.62 \\
Barley & 12.20 & 10.30 & 1.97 & 4.60 & 2.22 & 68.71 \\
Wheat bran & 11.50 & 14.97 & 3.40 & 9.48 & 4.92 & 58.40 \\
\hline
\end{tabular}

The rabbits were housed under the same environmental and hygieneconditions in wire cages $(60 \times 55 \times 40 \mathrm{~cm})$. Feed were offered to rabbits ad libitumby galvanized feeders and fresh tap water was available all the time by automatic drinkers.

At the end of the experimental period (12 weeks of age), five rabbits were randomly taken from each group and fasted for 12 hours before slaughtering to determine carcass characteristics. Slaughter procedure and carcass analysis were carried out as described by Blasco et al. (1993). After complete bleeding, pelt, viscera's and tail were removed then the carcass and its components were weighed as edible parts. The non-edible parts including lung, spleen, stomach, large intestine, small intestine and kidney fat were also weighed as percentage of pre-slaughter weight. Dressing percentage was calculated by dividing the hot dressed carcass weight by pre-slaughter weight and expressed as a percentage according to Steven et al. (1981).

Five blood samples were taken from each experimentalgroup at the time of slaughter for haemato-biochemical analysis. Each blood samples were taken into two tubes, the $1^{\text {st }}$ was supplemented with heparin as anticoagulationwhile, the $2^{\text {nd }}$ was without heparin. Plasma was separated by centrifugation of the blood at $3000 \mathrm{rpm}$ for 20 minutes and stored at $-20^{\circ} \mathrm{C}$ until performance of biochemical analysis

Blood plasma was analyzed for determination of glucose levels $(\mathrm{mg} / \mathrm{dl})$, total protein $(\mathrm{g} / \mathrm{dl})$, albumin $(\mathrm{g} / \mathrm{dl})$ and globulin $(\mathrm{g} / \mathrm{dl})$ whichwere measured according to Trinder (1969), Henry et al. (1974), Doumas (1971) and Coles(1974), respectively and different types of globulin $(\alpha-, \beta-$ and $\gamma-$ globulins) were determined according to Bossuyt et al. (2003). In addition, creatinine, urea-N, total lipids, triglycerides, total cholesterol, HDL and LDL were determined according to (Fabiny and Ertingshausen, 1971), (Sampson et al., 1980), (Chabrol and Charonnat, 1973), (Fossati and Prencipe, 1982), (Stein, 1986), (Lopez-Virella, 1977) and (Friedewald et al., 1972), respectively. Thyroid hormones $\mathrm{T}_{3}$ were analyzed by using radioimmunoassay kits as described by Sharp et al. (1987). 
The activity of Alkaline phosphates was measuredaccording to Belfield and Goldberg (1971) as well as activities of aspartate amino transferase (AST), and alanine amino transferase (ALT), were estimated according to Reitman and Frankle (1957).

White blood cells, red blood cells and different subclasses of WBC's (lymphocytes, neutrophils, monocytes, eosinophils and basophils percentages) were counted according to Feldman et al. (2000). Packed cell volume (PCV; $\%)$.

Haemoglobin concentration and red cell indices were determined according to the following equations:

Mean Corpuscular Hemoglobin $(\mathrm{MCH} ; \mathrm{Pg})=\mathrm{Hb} \times 10 /$ Red blood cell

Mean Corpuscular Hemoglobin Concentration(MCHC,g/dl) $=\underline{\mathrm{Hbx} 100}$

Packed cell volume

Total antioxidant capacity (TAC), superoxide dismutase (SOD) activity, glutathione peroxidase (GPX) activity and glutathione (GSH) activity were determined according to Koracevic et al. (2001), Misra and Fridovich (1972), Paglia and Valentine (1967) and (Ellman, 1959), respectively.

Phagocytic activity (PA) and index (PI) were determined according to Kawahara et al. (1991) as following equation:

$\mathrm{PA}=$ Percentage of phagocytic cells containing yeast cells.

PI = Number of yeast cell phagocytized / Number of phagocytic cells.

Serum immunoglobulins (IgY, $\operatorname{IgM}$ and $\operatorname{IgA}$ ) were determined using commercial ELISA kits (Kamiya Biomedical Company, USA) according to Bianchi et al. (1995).

Lymphocyte transformation test (LTT) was determined following the method described by Balhaa et al. (1985).

Serum bactericidal activity (BA) to Aeromonas hydrophila strain was determined according to Rainger and Rowley (1993).

Serum lysozyme activity was determined through the turbidimetry described by Hultmark et al. (1983) by using lyophilized Micrococcus lysodekticus $\left(\mathrm{OD}_{570 \mathrm{~nm}}=0.3\right)$ as the substrate in phosphate buffer $(0.1 \mathrm{M}, \mathrm{PH}$ 6.4 ). Fifty microlitres of fish serum was added to $3 \mathrm{ml}$ of bacterial suspension. The $570 \mathrm{~nm}$ absorbance-was-measured-after-mixture (Ao) and incubation for $30 \mathrm{~min}$ at $37^{\circ} \mathrm{C}(\mathrm{A})$. The result was expressed by the formula:

\section{Lysozyme activity $=($ Ao - A $) / A$}

The effect of dietary treatments on the microbial activity of the digestive system include: total bacteria count which was determined according to the method of ICMSF, 1980, as well as the detection of Salmonella and 
Escherichia coli strains following themethod of ISO-6579: 2002 food microbiology procedure employing the horizontal method of food and animal feeding stuffs (ISO Standards catalogue 07.100.30; WHO, 2010).

Data were statistically examined by analysis of variance (ANOVA) according to Snedecor and Chochran (1982) using SPSS system (2006) as the following model.

$$
\mathrm{Yij}=\mu+\mathrm{Ti}+\mathrm{eij}
$$

Where: $\mu=$ Overall mean of Yij, $\mathrm{T}=$ Effect of treatment, $\mathrm{i}=(1,2 \ldots$, etc $)$ and eij= Experimental error.

The differences between means were tested by using Duncan's New Multiple Range Test, (Duncan, 1955).

\section{RESULTSAND DISCUSSION}

\section{Carcass characteristics:}

The results for Pre-slaughter weight, g and carcass characteristics of NZW rabbits as affected by dietary supplementation with EZ are shown in Table 3. The results indicated that the rabbits fed diet containing 10 and 20\% DSM without EZ supplementation had lower final body weight. However, the rabbits fed diets containing $10 \%$ DSM with EZ supplementation was similar to the rabbits fed basal diet and significantly higher than the other groups.

On the other hand, the group fed $20 \%$ DSM with EZ showed significantly $(\mathrm{P}<0.05)$ greater final body weight than the $20 \%$ DSM without EZ supplementation. The negative effects of dietary addition DSM on rabbits growth performance agree with those reported by Masoudi et al. (2011) who found that rabbits fed diet containing date stone at levels of 10 and $20 \%$ had lower final body weight than the control group. This may be due to the low levels of protein and energy and high fibre level in DSM. This is agree with the results reported by Soliman et al. (2009), Ibrahim et al. (2010) and El-Manylawi and El-Banna (2013) who noted that adding EZ to diets contain DSM led to improve the rabbits growth performance. This improvement can be attributed to increase the digestibility and the nutrients availability of the ingested diet.

The rabbits fed $10 \%$ DSM with EZ presented significantly $(\mathrm{P}<0.05)$ higher percentages of dressing than the other groups. Carcass characteristics such as giblets ( liver, heart, kidney), lungs, stomach, abdominal fat, spleen, pancreas and cecum were not significantly affected by the treatments. However, the group fed the 20\% DSM with EZwas significantly higher percentages of intestinal than the other groups. The present results indicate that dietary DSM addition had no 
Table (3): Carcass characteristics and relative weight of internal organs of NZW rabbits fed diets containing different levels of date stones meal (DSM).

\begin{tabular}{|c|c|c|c|c|c|c|c|}
\hline \multicolumn{6}{|c|}{ Experimental diets (\%) } & \multirow[b]{2}{*}{ SEM } & \multirow[b]{2}{*}{ Sig. } \\
\hline Items & $\begin{array}{c}\text { Control } \\
(0)\end{array}$ & $\begin{array}{l}10 \% \\
\text { DSM }\end{array}$ & $\begin{array}{c}10 \% \\
\mathrm{DSM}+ \\
\mathrm{EZ}\end{array}$ & $\begin{array}{l}20 \% \\
\text { DSM }\end{array}$ & $\begin{array}{c}20 \% \\
\text { DSM+ } \\
\text { EZ }\end{array}$ & & \\
\hline $\begin{array}{l}\text { Preslaughter } \\
\text { weight, g }\end{array}$ & $1885^{\mathrm{a}}$ & $1731^{c}$ & $1898^{\mathrm{a}}$ & $1656^{\mathrm{d}}$ & $1790^{\mathrm{b}}$ & 18.6 & 0.001 \\
\hline Dressing (\%) & $59.33^{\mathrm{b}}$ & $\underset{c}{56.36^{b}}$ & $64.05^{\mathrm{a}}$ & $54.91^{\mathrm{c}}$ & $57.18^{\mathrm{bc}}$ & 1.034 & 0.006 \\
\hline Heart (\%) & 0.44 & 0.44 & 0.39 & 0.41 & 0.41 & 0.215 & 0.506 \\
\hline Liver $(\%)$ & 2.65 & 3.48 & 3.15 & 3.53 & 3.33 & 0.215 & 0.078 \\
\hline Kidney (\%) & 0.76 & 0.82 & 0.83 & 0.78 & 0.74 & 2.246 & 0.433 \\
\hline Giblet (\%) & 3.85 & 4.64 & 4.37 & 4.72 & 4.48 & $? ?$ & $? ?$ \\
\hline Lungs (\%) & 0.54 & 0.700 & 0.630 & 0.62 & 0.660 & 0.044 & 0.207 \\
\hline $\operatorname{Stomach}(\%)$ & 2.26 & 2.380 & 2.570 & 2.86 & 2.590 & 0.255 & 0.527 \\
\hline Intestinal(\%) & $2.94^{\mathrm{b}}$ & $2.60^{\mathrm{b}}$ & $2.48^{\mathrm{b}}$ & $4.33^{\mathrm{a}}$ & $3.55^{\mathrm{ab}}$ & 0.41 & 0.026 \\
\hline $\begin{array}{l}\text { Abdominal fat } \\
(\%)\end{array}$ & 1.370 & 1.050 & 1.440 & 1.22 & 1.090 & 0.107 & 0.071 \\
\hline Spleen (\%) & 0.070 & 0.070 & 0.080 & 0.07 & 0.050 & 0.008 & 0.128 \\
\hline Pancreas(\%) & 0.140 & 0.150 & 0.190 & 0.22 & 0.130 & 0.025 & 0.118 \\
\hline $\operatorname{Cecum}(\%)$ & 1.830 & 2.460 & 2.020 & 2.05 & 2.340 & 0.181 & 0.135 \\
\hline \multicolumn{8}{|c|}{$\begin{array}{l}\text { a,b Values within a row with different superscripts differ significantly }(P<0.05) \text {. } \\
\text { SEM, Standard error of mean's. }\end{array}$} \\
\hline \multicolumn{8}{|c|}{$\begin{array}{l}\text { effects on internal organs weights. These results are disagreement with the results } \\
\text { reported by Garcia et al. (1999) who reported that carcass weight was reduced } \\
\text { when adding } 6 \text { and } 10 \% \text { palm kernel cake in broiler diets. However, Al-Harthi et } \\
\text { al. (2009) showed that carcass weight, dressing and intestine length of hens fed } \\
\text { dietary date waste meal containing diets had no significant differences. While, } \\
\text { abdominal fat percent was decreased ( } \mathrm{P} \leq 0.05) \text { with increasing date waste meal } \\
\text { inclusion level up to } 20 \% \text {. Similarly, Toson et al. (1995) reported that } \\
\text { inclusion of DSM to replace up to } 20 \% \text { of rabbits basal diet had no adverse } \\
\text { effect on carcass traits of growing rabbits. Also, Masoudi et al. (2011) } \\
\text { revealed that the carcass characteristics of broiler chickens fed diets containing } \\
\text { date stone showed the same dressed weight and liver percentage as the control. }\end{array}$} \\
\hline
\end{tabular}


Furthermore, Attia, and Al-Harthi (2015) found that inclusion of different concentrations of date stoneshad not significantly effect on dressed carcass weight and total edible parts percentage.

The improvement in dressing percentage in groups fed 10\% DSM plus EZ may be attributed to that EZ supplementation increased the digestibility and availability of nutrients in the low density diets containing DSM therefore improved the percentages of dressing. This results agree with those reported by Ibrahim et al. (2010) who revealed that kemzyme addition to diets containing 50 or $100 \%$ ground date stone increased the dressing percentage compared to the other groups. Also, Attia et al. (2014) found that multienzymes addition to broiler diets led to increase in relative dressingweight and total edible parts compared to the control group. Similarly, Attia et al. (2003) and Salem et al. (2003) concluded that the improvement in carcass yield due to enzyme supplementation is a reflection of increase in nutrient availability for tissue growth. However, El-Manylawi and El-Banna (2013) showed that replacing DSM at levels 10 or $20 \%$ without or with Allzyme $®$ SSF in the diets, led to insignificant differences in dressing and giblets $\%$ of rabbits compared to the control.

\section{Chemical composition of rabbits meat :}

The chemical characteristics of rabbit meat as affected by feeding DSM and EZare shown in Tables 4. Protein and lipid percentage of meat was significantly lower in rabbit fed 10 and 20\% DSM with EZ as compared to those fed the control diet. Moreover, the groups fed $10 \%$ DSM with EZ showed significantly higher moisture percentage in rabbits meat than those fed 10 and 20\% DSM without EZ. While, Meat ash percentage showed no significant differences between groups.In harmony with the obtained results of meat quality, El-Manylawi and El-Banna (2013) showed that dietary inclusion of DSM at 10 and $20 \%$ of the diet reduced the ether extract of meat compared to the control group, while, moisture of meat was reduced at dietary addition of $20 \%$ DSM compared to the control group. Similarly, Attia et al. (2014) found that meat protein percentage was increased while meat moisture decreased by multienzymes addition in diets. This indicate that multienzymes addition to improvement in meat quality traits. However, there was no significant effect of inclusion of whole inedible dates in diets up to $15 \%$ on dry matter, crude protein, ether extract and ash of meat (El-Deek et al., 2010).

Similarly, Al-Homidan (2003) observed that whole inedible dates did not significantly affect carcass quality of broilers. Also, Abaza and Omara (2011) recorded insignificant differences in the chemical composition of NZW rabbit meat due to feeding diets supplemented with EZ. 
Table (4). Meat quality of NZW rabbits fed diets containing different levels of date stone meal (DSM).

\begin{tabular}{lccccccc}
\hline \multirow{2}{*}{ Items } & \multicolumn{7}{c}{ Experimental diets (\%) } \\
\cline { 2 - 8 } & \multirow{2}{*}{ Control } & $\begin{array}{c}\mathbf{1 0} \% \\
\text { DSM }\end{array}$ & $\begin{array}{c}\mathbf{1 0} \% \\
\text { DSM + EZ }\end{array}$ & $\begin{array}{c}\mathbf{2 0} \text { \% } \\
\text { DSM }\end{array}$ & $\begin{array}{c}\text { \%0 } \\
\text { \%SM+EZ }\end{array}$ & SEM & \multirow{2}{*}{ Sig. } \\
\hline Moisture & $67.78^{\mathrm{a}}$ & $66.32^{\mathrm{bc}}$ & $71.28^{\mathrm{a}}$ & $62.84^{\mathrm{c}}$ & $69.48^{\mathrm{ab}}$ & 1.533 & 0.010 \\
Protein & $22.47^{\mathrm{a}}$ & $20.55^{\mathrm{ab}}$ & $21.57^{\mathrm{a}}$ & $19.43^{\mathrm{b}}$ & $21.66^{\mathrm{a}}$ & 0.67 & 0.041 \\
ASH & 1.154 & 1.142 & 1.164 & 1.186 & 1.176 & 0.018 & 0.448 \\
Lipid & $5.520^{\mathrm{a}}$ & $5.120^{\mathrm{ab}}$ & $5.380^{\mathrm{a}}$ & $4.300^{\mathrm{b}}$ & $5.480^{\mathrm{a}}$ & 0.303 & 0.054 \\
\hline a,b Values within a row with different superscripts differ significantly $(P<0.05)$. & \\
SEM, Standard error of mean's.
\end{tabular}

\section{The blood constituents:}

The results of blood biochemical constituents of NZW rabbits fed DSM supplemented with EZ are shown in Table 5. Feeding 10\% DSM plus EZ and control diets resulted in significantly higher total lipid, triglycerides, HDL, LDL and glucose than those fed the other groups, however, the difference between rabbits fed 10 and 20\% DSM plus EZ were not significant in HDL and LDL. In addition, rabbits fed 20\% DSM diets with or without EZ had significantly higher urea-N than other groups. On the other hand, rabbits fed 10 and 20\% DSM with EZ had significantly $(\mathrm{P}<0.05)$ higher $\mathrm{T}_{3}$ than those fed20\% DSM without EZ supplementation. Moreover, rabbits fed10\% DSM with EZand controldiets had significantly lower GPX and SOD than the other groups.

No significant differences were recorded in total protein, albumin, AST, ALT, alkaline phosphates, cholesterol, creatinine, TAC and GSH among the different experimental groups. The present results of biochemical constituents of blood are in agreement with the results reported by Al-Bowait and AlSultan (2006) who reported that blood glucose levelwas not significantly affected in birds fed diet containing date stones. Similarly, El-Deek et al. (2008) and Al-Harthi et al. (2009) found insignificant reduction in plasma total protein levels in rabbits fed diet containing date waste meal. Also, There was no significant effect of addition of date stones to diets on HDL (Masoudi et $a l ., 2011)$. The present results agree with these reported by Mousa (2013) who found that concentrations of serum cholesterol, glucose and activity of SALT and SAST did not significantly differ among the three experimental groups fed date stones. Similarly, Attia and Al-Harthi (2015) reported that broilers can be fed date waste up to $200 \mathrm{~g} / \mathrm{kg}$ from 21 to 40 days of age without adverse 
effects on protein metabolism and liver and renal functions. El-Kelawy and ElKelawy (2016) showed that glucose was significantly $(\mathrm{P}<0.05)$ higher in rabbits fed diet supplemented with EZ compared to those fed basal diet (control).

On the other hand, there was no significant effect of EZ supplementations on blood plasma albumin, total lipids, cholesterol, creatinine, AST, ALT and alkaline phosphates. Also, results regarding albumin and globulin are in agreement with those reported by Abaza and Omara (2011) who found no significant changes in the levels of the albumin and globulin in the blood of rabbits fed diets supplemented with EZ. Results regarding blood glucose are in agreement with those reported by Attia et al. (2012) who recorded significant increase in blood glucose of rabbits supplemented with kemzyme compared to controls. Also, Saleh et al., (2006) found that kemzyme supplementation to the ration of growing turkey resulted in a significant increase level of blood glucose (within normal range). They attributed such finding to the improvement of digestibility and metabolism of different nutrients in the diet by the addition of exogenous enzymes thus, actively affects the blood levels of basic nutrients (Mathlouthi et al., 2003). Moreover, dates and date stones are a good source of antioxidants, mainly carotenoids and phenolics (Al-Farsi and Lee, 2008). Masoudi et al. (2011) found that blood glucose concentration was increased while, the triglyceride and LDL concentration were not significantly different between control and date stones diets. Furthermore, Mousa (2013) found that serum total protein, albumin and globulin for growing rabbits significantly $(\mathrm{P}<0.05)$ decreased by $30 \%$ date stone inclusion in the diet compared with those fed control or $20 \%$ date stones diets.

\section{Blood hematological parameters}

Enzyme supplementation to $10 \%$ DSM diet resulted in significantly higher RBC's than the control and other groups. Nevertheless, the other blood plasma components, haematological criteria and differential leucocytes counts were not significantly affected by the dietary treatments (Table 6).

The present results of blood hematological parameters are in agreement with the results reported by Afsari et al., (2013) who stated that date stones and olive pulp with non-phytate phosphorus and phytase supplementation did not significantly affect white blood cell count (heterophils, eosinophils, basophils, lymphocytes and monocytes). Also, Kurtong (2014) found that rabbits fed diets supplemented with EZ showed no significant difference (P>0.05) for, Hb, WBC and PCV among all treatments. Results of El-Kelawy 
Table (5): Blood biochemical constituents of NZW rabbits fed diets containing different levels of date stones meal (DSM).

\begin{tabular}{|c|c|c|c|c|c|c|c|}
\hline \multirow[b]{2}{*}{ Items } & \multicolumn{7}{|c|}{ Experimental diets (\%) } \\
\hline & Control & $\begin{array}{l}10 \% \\
\text { DSM }\end{array}$ & $\begin{array}{l}10 \% \\
\text { DSM+ } \\
\text { EZ }\end{array}$ & $\begin{array}{l}20 \% \\
\text { DSM }\end{array}$ & $\begin{array}{c}20 \% \\
\text { DSM } \\
+ \text { EZ }\end{array}$ & SEM & Sig. \\
\hline Total protein (g/dl) & 5 & 4.95 & 5 & 4.75 & 4.95 & 0.155 & 0.771 \\
\hline Albumin (g/dl) & 2.2 & 2.28 & 2.08 & 2.48 & 2.2 & 0.093 & 0.074 \\
\hline $\operatorname{AST}(\mathbf{U} / \mathbf{L})$ & 20.5 & 22 & 22.4 & 20.1 & 18 & 1.029 & 0.059 \\
\hline $\operatorname{ALT}(\mathbf{U} / \mathbf{L})$ & 62.3 & 57 & 59.3 & 59.3 & 59 & 1.228 & 0.083 \\
\hline $\begin{array}{l}\text { Alkaline } \\
\text { phosphates(IU/L) }\end{array}$ & 12.8 & 12.8 & 12.3 & 13.5 & 14.3 & 0.547 & 0.452 \\
\hline Urea (mg/dl) & $17.2^{\mathrm{b}}$ & $17.5^{\mathrm{b}}$ & $17.9^{\mathrm{b}}$ & $19.7^{\mathrm{a}}$ & $20.0^{\mathrm{a}}$ & 0.341 & 0.001 \\
\hline Creatinine (mg/dl) & 0.975 & 0.8 & 0.9 & 0.875 & 1.003 & 0.049 & 0.06 \\
\hline Total lipid (mg/dl) & $456^{\mathrm{a}}$ & $384^{\mathrm{b}}$ & $440^{\mathrm{a}}$ & $400^{\mathrm{b}}$ & $384^{\mathrm{b}}$ & 6.314 & 0.001 \\
\hline Triglycerides(mg/dl) & $167^{\mathrm{b}}$ & $164^{\mathrm{c}}$ & $171^{\mathrm{a}}$ & $165^{\mathrm{c}}$ & $166^{\mathrm{c}}$ & 1.625 & 0.001 \\
\hline Cholesterol (mg/dl) & 185 & 184 & 180 & 184 & 181 & 1.666 & 0.365 \\
\hline HDL(mg/dl) & $41.3^{\mathrm{b}}$ & $41.5^{\mathrm{b}}$ & $43.3^{\mathrm{a}}$ & $40.8^{\mathrm{b}}$ & $42.5^{\mathrm{ab}}$ & 0.55 & 0.029 \\
\hline LDL(mg/dl) & $97.8^{\mathrm{ab}}$ & $93.5 c^{d}$ & $98.3^{\mathrm{a}}$ & $92.3^{\mathrm{d}}$ & $95.5 b^{c}$ & 0.885 & 0.003 \\
\hline Glucose (mg/dl) & $83.3^{\mathrm{ab}}$ & $78.3^{\mathrm{b}}$ & $85.0^{\mathrm{a}}$ & $78.5^{\mathrm{b}}$ & $80.3^{\mathrm{ab}}$ & 1.781 & 0.054 \\
\hline T3 (ng / ml) & $2.21^{\mathrm{ab}}$ & $2.21^{\mathrm{ab}}$ & $2.25^{\mathrm{a}}$ & $2.16^{\mathrm{b}}$ & $2.23^{\mathrm{a}}$ & 0.019 & 0.024 \\
\hline TAC (mg/dl) & 420 & 422 & 420 & 421 & 422 & 1.567 & 0.76 \\
\hline GPX $\overline{(\mathrm{mg} / \mathrm{dl})}$ & $0.475^{\mathrm{b}}$ & $0.525^{\mathrm{a}}$ & $0.450^{\mathrm{b}}$ & $0.523^{\mathrm{a}}$ & $0.508^{\mathrm{a}}$ & 0.01 & 0.016 \\
\hline GSH (mg/dl) & 989 & 996 & 990 & 990 & 997 & 2.072 & 0.065 \\
\hline SOD $\underline{(\mathrm{mg} / \mathrm{dl})}$ & $239^{\mathrm{b}}$ & $244^{\mathrm{a}}$ & $239^{\mathrm{b}}$ & $247^{\mathrm{a}}$ & $244^{\mathrm{a}}$ & 1.321 & 0.001 \\
\hline
\end{tabular}

a,b...d Values within a row with different superscripts differ significantly $(P<0.05)$.

SEM, Standard error of mean's; AST=Aspartate amino transferase; ALT=Alanine amino transferase; HDL=High-density lipoprotein; LDL=Low-density lipoprotein; T3= Triiodothyronine; $\mathrm{T} 4=$ Thyroxine; $\mathrm{TAC}=$ Total antioxidant capacity; GPX $=$ Glutathione peroxidase; $\mathrm{GSH}=$ Glutathione; $\mathrm{SOD}=$ Superoxide dismutase.

and El-Kelawy (2016) suggested that Hemoglobin, PCV, MCV, MCH, MCHC, WBC's and differential leukocytes counts were not significantly affected by EZ supplementation to rabbits diets.

Enzyme supplementation to $10 \%$ DSM diet resulted in significantly higher $\beta$-globulin than the other groups. Moreover, rabbits fed 10\% DSM with 
EFFECT OFADDINGOF KEMZYMETODIETCONTAININGDATE STONEMEALONRABBITS. 497

Table (6): Blood hematological constituents of NZW rabbits fed diets containing different levels of date stones meal (DSM).

\begin{tabular}{|c|c|c|c|c|c|c|c|}
\hline \multirow[b]{2}{*}{ Items } & \multicolumn{5}{|c|}{ Experimental diets (\%) } & \multirow[b]{2}{*}{ SEM } & \multirow[b]{2}{*}{ Sig. } \\
\hline & Control & $\begin{array}{l}10 \% \\
\text { DSM }\end{array}$ & $\begin{array}{l}10 \% \\
\text { DSM } \\
+\mathrm{EZ}\end{array}$ & $\begin{array}{l}20 \% \\
\text { DSM }\end{array}$ & $\begin{array}{l}20 \% \\
\text { DSM+ } \\
\text { EZ }\end{array}$ & & \\
\hline RBC's $\left(10^{6} / \mathrm{cmm}^{3}\right)$ & $1.45 b$ & $1.45 \mathrm{~b}$ & $1.68 \mathrm{a}$ & $1.50 \mathrm{~b}$ & $1.40 \mathrm{~b}$ & 0.057 & 0.026 \\
\hline $\begin{array}{l}\text { Hemoglobin } \\
\text { (g/100ml) }\end{array}$ & 9.50 & 10.00 & 9.75 & 10.75 & 10.00 & 0.354 & 0.179 \\
\hline PCV \% & 29.00 & 30.30 & 29.50 & 30.30 & 29.80 & 0.879 & 0.831 \\
\hline MCH (Ug) & 201.0 & 210.0 & 198.0 & 181.0 & 215.0 & 2.986 & 0.098 \\
\hline MCHC (\%) & 65.80 & 69.50 & 65.40 & 64.30 & 72.00 & 0.895 & 0.36 \\
\hline WBC's $\left(10^{3} / \mathrm{cmm}^{3}\right)$ & 32.70 & 33.10 & 33.00 & 35.70 & 33.60 & 0.444 & 0.164 \\
\hline Monocytes $\left(10^{3}\right)$ & 4.50 & 4.50 & 3.75 & 5.00 & 4.25 & 0.308 & 0.109 \\
\hline Basophils $\left(10^{3}\right)$ & 0.50 & 0.50 & 1.00 & 1.00 & 0.50 & 0.224 & 0.24 \\
\hline Eosinophils $\left(10^{3}\right)$ & 9.50 & 9.50 & 9.75 & 8.75 & 9.75 & 0.377 & 0.348 \\
\hline Neutrophils $\left(10^{3}\right)$ & 49.50 & 50.00 & 50.00 & 48.80 & 48.80 & 0.886 & 0.735 \\
\hline Lymphocytes $\left(10^{3}\right)$ & 36.00 & 35.50 & 35.50 & 36.50 & 36.80 & 0.444 & 0.202 \\
\hline
\end{tabular}

${ }^{\mathrm{a}, \mathrm{b}}$ Values within a row with different superscripts differ significantly at $P<0.05$.

SEM, Standard error of mean's; RBC's= Red blood cell; PCV=Packed cell volume; $\mathrm{MCH}=$ Mean corpuscular hemoglobin; WBC's=White blood cell

or without EZ and control groups had significantly higher $\alpha-$ globulin, BA and LTT than those fed diet containing 20\% DSM with or without EZ. However, the differences between the 10 and 20\%DSM with EZ was not significant in BA and LTT. In addition, EZ supplementation to diet containing 10 and 20\% DSM and control diet resulted in significantly higher $\operatorname{IgA}, \operatorname{IgM}$ and $\operatorname{IgG}$ than the other DSM groups. However, the differences between 10\% DSM with or without EZ were not significant in $\operatorname{IgA}$.

\section{Immune response}

On the other hand, no significant differences were recorded in globulin, $\gamma$ - globulin, LA, PI and PA among the experimental groups (Table 7). El-Kelawy and El-Kelawy (2016) showed that rabbits fed diet supplemented with EZ had significant higher PA\% than those fed basal diet (control).In addition, However, Attia, and Al-Harthi (2015) reported that inclusion of date waste up to $200 \mathrm{~g} / \mathrm{kg}$ did not affect antibody titers to NDV at 40 days of age. 
Table (7): Immune indices in blood of NZW rabbits fed diets containing different levels of date stones meal (DSM).

\begin{tabular}{|c|c|c|c|c|c|c|c|}
\hline \multirow[b]{2}{*}{ Items } & \multicolumn{7}{|c|}{ Experimental diets (\%) } \\
\hline & Control & $\begin{array}{l}10 \% \\
\text { DSM }\end{array}$ & $\begin{array}{l}10 \% \\
\text { DSM } \\
+ \text { EZ }\end{array}$ & $\begin{array}{l}20 \% \\
\text { DSM }\end{array}$ & $\begin{array}{l}20 \% \\
\text { DSM+ } \\
\text { EZ }\end{array}$ & SEM & Sig. \\
\hline Globulin (g/dl) & 2.80 & 2.68 & 2.93 & 2.28 & 2.75 & 0.171 & 0.12 \\
\hline$\alpha$-globulin (g/dl) & $1.08^{\mathrm{a}}$ & $1.08^{\mathrm{a}}$ & $1.13^{\mathrm{a}}$ & $0.900^{\mathrm{b}}$ & $0.925^{\mathrm{b}}$ & 0.046 & 0.007 \\
\hline B-globulin (g/dl) & $0.750^{\mathrm{b}}$ & $0.850^{\mathrm{b}}$ & $1.000^{\mathrm{a}}$ & $0.825^{\mathrm{b}}$ & $0.850^{\mathrm{b}}$ & 0.044 & 0.013 \\
\hline Globulin- $\gamma(\mathrm{g} / \mathrm{dl})$ & 0.975 & 0.75 & 0.8 & 0.55 & 0.975 & 0.175 & 0.417 \\
\hline LA (IU\%) & 0.09 & 0.115 & 0.103 & 0.118 & 0.103 & 0.007 & 0.067 \\
\hline BA $(\%)$ & $37.8^{\mathrm{c}}$ & $38.5^{\mathrm{bc}}$ & $41.0^{\mathrm{a}}$ & $37.3^{\mathrm{c}}$ & $40.3^{\mathrm{ab}}$ & 0.61 & 0.001 \\
\hline LTT(\%) & $30.5^{\mathrm{c}}$ & $29.3^{c}$ & $34.5^{\mathrm{a}}$ & $31.5^{\mathrm{bc}}$ & $33.5^{\mathrm{ab}}$ & 0.963 & 0.006 \\
\hline PI (\%) & 1.780 & 1.800 & 1.800 & 1.780 & 1.850 & 0.760 & 0.956 \\
\hline PA $(\%)$ & 16.30 & 18.00 & 18.30 & 16.50 & 17.80 & 0.577 & 0.075 \\
\hline IgA (mg/100 ml) & $86.1^{\mathrm{a}}$ & $83.5^{\mathrm{ab}}$ & $86.3^{\mathrm{a}}$ & $83.0^{\mathrm{b}}$ & $86.5^{\mathrm{a}}$ & 0.979 & 0.035 \\
\hline IgM (mg/100 ml) & $242^{\mathrm{a}}$ & $237^{\mathrm{b}}$ & $241^{\mathrm{a}}$ & $235^{\mathrm{b}}$ & $240^{\mathrm{a}}$ & 1.49 & 0.046 \\
\hline IgG (mg/100 ml) & $983^{\mathrm{a}}$ & $980^{\mathrm{b}}$ & $987^{\mathrm{a}}$ & $978^{\mathrm{b}}$ & $985^{\mathrm{a}}$ & 1.49 & 0.01 \\
\hline
\end{tabular}

Microbial activity of the digestive system

The microbial activity of the digestive system of rabbit as affected by DSM and EZ supplementation are shown in Tables 8. The groups on the 10 and $20 \%$ DSM with or without EZ showed significantly lower total bacterial count, Salmonella, E. Coli and Proteus than the control groups. This results of microbial activity of the digestive system are in agreement with the results reported by El-Deek et al. (2008) who found that total bacteria, E. coli and fungi group counts were decrease with increasing the dietary date waste meal level up to $15 \%$ as compared to those of the control group. Also, this finding agree with that of Al-Harthi et al. (2009) who found that the total bacteria and E. coli were decreased with inclusion date waste meal up to $20 \%$ of the diet. Also, Abd El-Megeed (2016) revealed that total bacterial counts on the jejunum contents showed a decrease when used the date stones in broiler chicks diets. The improvement in performance of rabbits with multienzymes 
EFFECT OFADDINGOFKEMZYMETODIETCONTAININGDATE STONEMEALONRABBITS. 499

Table (8). Microbial activity in digestive canal of NZW rabbits fed diets containing different levels of date stones meal (DSM).

\begin{tabular}{lccccccc}
\hline & \multicolumn{7}{c}{ Experimental diets (\%) } \\
\cline { 2 - 8 } Items & Control & $\begin{array}{c}\mathbf{1 0 \%} \\
\text { DSM }\end{array}$ & $\begin{array}{c}\mathbf{1 0} \% \\
\text { DSM + } \\
\text { EZ }\end{array}$ & $\begin{array}{c}\mathbf{2 0} \% \\
\text { DSM }\end{array}$ & $\begin{array}{c}\mathbf{2 0} \text { DSM+ } \\
\text { DSZ }\end{array}$ & SEM & Sig. \\
\hline TBC & $6250^{\mathrm{a}}$ & $3850^{\mathrm{b}}$ & $4000^{\mathrm{b}}$ & $3500^{\mathrm{b}}$ & $2750^{\mathrm{b}}$ & 456 & 0.004 \\
E. coli & $4000^{\mathrm{a}}$ & $1600^{\mathrm{b}}$ & $2500^{\mathrm{b}}$ & $2950^{\mathrm{b}}$ & $1150^{\mathrm{b}}$ & 682 & 0.002 \\
Salmonella & $5250^{\mathrm{a}}$ & $1375^{\mathrm{b}}$ & $2300^{\mathrm{b}}$ & $2425^{\mathrm{b}}$ & $1250^{\mathrm{b}}$ & 589 & 0.022 \\
Proteus & $1800^{\mathrm{a}}$ & $625^{\mathrm{b}}$ & $1050^{\mathrm{b}}$ & $1000^{\mathrm{b}}$ & $1000^{\mathrm{b}}$ & 175 & 0.003 \\
Mortality rate & 0.0 & 0.0 & 0.0 & 0.0 & 0.0 & -- & -- \\
\hline
\end{tabular}

${ }^{a, b}$ Values within a row with different superscripts differ significantly $(P<0.05)$.

SEM, Standard error of mean's.

addition may be due to a reduction in counts of pathogens, Gram-positive cocci, total anaerobes, and enterococci bacteria in the intestines (Tabook et al., 2006).

In conclusion, date stones meal can be included in the rabbit diets up to $10 \%$ with adding enzyme complex (Kemzyme) without adverse effects on body weights, blood parameters, immune index, carcass characteristics and meat quality.

\section{REFERENCES}

Abaza, M. and Omara, M. E. (2011). Effect of dietary corn cobs and enzymes supplementation on growing rabbits performance. Journal of Production and Development, 16(3): 507-527.

Abd El Megeed, A. H.(2016).Nutritional Value of Date Seed in Broiler Rations. $2^{\text {nd }}$ International Conference for date palm (ICDP 2016), from 10-12 October, 2016, Qassim, Kingdom of Saudi Arabia.

Abd El-Latif, S.A.; Mohammed, Kh. A.; Ghaly, Kawsar A. and Abd ElLatif,Maha A. (2008). Effect of using commercial enzymes on performance and some metabolic functions of rabbits fed grade levels of crude fiber. Egyptian Poultry Science, 28: 1003-1022. 
Afsari, M.;Mohebbifar, A. and Torki, M. (2013). Effects of Phytase Supplementation of Low Phosphorous Diets Included Olive Pulp and Date Pits on Productive Performance of Laying Hens, Egg Quality Traits and Some Blood Parameters.Annual Review \& Research in Biology, 3(4): 777-793.

Al-Bowait, M and Al-Sultan, S.I. (2006). Aspects of the serum biochemistry, carcass quality and organoleptic characteristics of broilers fed alkalitreated date pits. International Journal of Poultry Science, 5: 284-288.

Aldhaheri, A.; Alhadrami, G.;Aboalnaga, N.; Wasfi, I. and Elridi, M. (2004).Chemical composition of date pits and reproductive hormonal status of rats fed date pits. Food Chemical, 86: 93-97.

AL-FARSI, M.A. and C.Y. LEE, (2008). Nutritional and Functional Properties of Dates: A Review. Crit. Rev. in Food Scienceand Nutrition, 48: 877-887.

Al-Harthi, M.A.; El-Deek, A.A.; Yakout, H.M. and AL-Refaee, M. (2009).The nutritive value of date waste meal as a feedstuff for Lohmann Brown pullets and layers. Journal Poultry Science, 46: 303-312.

AL-Homidan, A.H. (2003). Date waste, whole dates and date pits as ingredients in broiler diets. Egyptian Poultry Science,23: 15-35.

AOAC (2004). Association of Official Analytical Chemists International: Official Methods of Analysis of AOAC International. $18^{\text {th }}$ edition, AOAC International, Gaithersburg, MD, USA.

Attia, Y. A.; Al-Harthi, M. A. and El-Deek, A. A. (2003). Nutritive value of undehulled sunflower meal as affected by multienzymes supplementation to broiler diets. Archiv Für Geflügelk, 67:97-106.

Attia, Y.A. and M.A. Al-Harthi, (2015).Effect of supplementation of date waste to broiler diets on performance, nutrient digestibility, carcass characteristics and physiological parameters. European Poultry Science, 79: ISSN 1612-9199. DOI: 10.1399/eps.2015.91

Attia, Y.A.; El-Tahawy, W.S.; Abd El-Hamid, A.E.; Nizza, A.; ElKelaway, M.I.; Al-Harthi, M.A. and Bovera, F. (2014). Effect of feed form, pellet diameter and enzymes supplementation on carcass characteristics, meat quality, blood plasma constituents and stress indicators of broilers. Archiv Tierzucht, 57(30): 1-14. 
Attia. K. A.; Sohair, Y.S.; Abd Elhamid Safaa, S.; ZakiAmal A. and M. ElSawy A. (2012). Effects of exogenous multi-enzyme feed additive (kemzyme) on the activities of certain digestive enzymes and intestinal morphology in growing rabbits. Journal of Agricultural Science, 4: 35-44.

Balhaa, R. L.; Hinz, H. H.; Luders, H. and Siegmann, O. (1985).Clinical experiences with the drugs for lymphocyte transformation in chickens and turkey flocks. Tiera Rztlicheum Schau, 43: 507-508.

Belfield, A. and Goldberg D. (1971).Colorimetric determination of alkaline phosphatase activity. Enzyme, 12:561-566.

Bianchi, A. T. J.; Moonen-Leusen, H. W. M.; van der Heijden, P. J. and Bokhout, B. A. (1995). The use of a double antibody sandwich ELISA and monoclonal antibodies for the assessment of porcine $\operatorname{IgM}, \operatorname{IgG}$, and IgA concentrations. Vet. Immunol. Immunopathol., 44:309-317.

Blasco, A., J. Quhayaun and G. Masoscro, (1993): Harmonization of criteria and terminology in rabbit meat research. World Rabbits Sciences, 1: 3-10.

Bossuyt, X.; Lissoir, B.; Mariën, G.; Maisin, D.; Vunckx, J.; Blanckaert, N. and Wallemacq, P. (2003). Automated Serum Protein Electrophoresis by Capillarys. Clin. Chem. Lab. Med. ; 41(5):704-710.

Chabrol, E. and Charonnat, R. (1973). Determination of plasma total lipids. Press Medical, 45: 17131720.

Coles, E. H. (1974). Veterinary Clinical Pathology. IST ED. 211-213 W.B. saunder, company, Philadelphia, London, Toronto.

Cheeke, P. R. (1987). Rabbit Feeding and Nutrition. Orlando: Academic Press, Inc. Harcourt, Brace, Jovanovich, Publishers.

Doumas, B. (1971). Colorimetric determination of serum albumin. Clin. Chim. Acta, 31: 400-403.

Duncan, D. B. (1955).Multiple range and multiple "F" test. Biometrics, 11,1-42.

El-Deek, A.A.;Al-Harthi, M.A. and Yakout, H.M. (2008). Use of enzymes to supplement diets containing date waste meal for Lohmann White Layers. International Journal of Poultry Science, 7, 397-407.

El-Deek, A.A.;Attia, Y.A. and Al-Harthi, M.A. (2010). Including whole inedible date in grower-finisher broiler diets and the impact on productive performance, nutrient digestibility and meat quality. Animal, 4:1647-1652.

El-Kelawy, H. M. and El-Kelawy, M. I. (2016). Impact of dietary supplementation with multi enzyme and/or probiotic on growth performance, nutrients digestibility and blood constituents of growing rabbits. Egyptian Journal Nutrition and Feeds, 19 (2): 313-323. 
Ellman, G. L. (1959). Tissue sulfhydryl groups.. Arch. Biochem Biophys., 82: 70-77.

El-Manylawi, M. A. and El-Banna, H. M. (2013).Effect of feeding date stone meal supplemented with Allzyme ${ }^{\circledR}$ on performance of growing New Zealand Rabbits. Egyptian Journal Animal Production, 50(2):103-109.

El-Sayaad, G.A. (2002).New Feedstuffs resources in rabbit nutrition. $3^{\text {rd }}$ Science. Conference on Rabbit Prod. In Hot Climates, 8-11 October, 461-467.

Fabiny, D.L. and Ertingshausen, G. (1971) Automated reaction-rate method of serum creatinine with the centrifichem. Clinical Chemistry, 17(8):696-700

Feldman, B. F.; Zinkl, J. G. and Jain, N. C. (2000).Schalm's Veterinary Hematology. Lippincott Williams and Wilkins, Philadelphia, USA.

Fossati, P. and Prencipe, L. (1982). Serum triglycerides determined colorimetrically with an enzyme that produces hydrogen peroxide. Clinical Chemistry, 28: 2077-2080.

Friedewald, W. T.; Levy, R. T. and Frederickson, D. S.1 (972).Estimation of the concentration of low-density lipoprotein cholesterol in plasma without use of the preparative ultracentrifuge. Clinical Chemistry, 18: 499-502.

Gaber, M. M.;Labib, E. H.; Omar, E. A.; Zaki,M. A. and Nour, A. M. (2012). Effect of Partially Replacing Corn Meal by Date Stone on Growth Performance in Nile Tilapia (OreockromisNiloticus) Fingerlings, Diets Supplemented with Digestarom®. Open Access Scientific Reports, 1(10):1-5

Garcia, C.A.; Gernat, A.G. and Murillo, J.G. (1999). The effect of four levels of palm kernel meal in broiler diets. CEIBA, 40: 29-295

Henry, R.; Cannon, D. and Winkelman, J. (1974). Clinical Chemistry, Principles And Techniques. $2^{\text {nd }}$ edition, Harper and Row, New York, USA

Hultmark, D.; Engstrom, A.; Anderson, K.; Engstrom, A.; Andersson, K.; Steiner, H.; Bennich H. and Boman, H.G. (1983). Insect immunity. Attacins, a family of antibacterial proteins from Hyalophora cecropia. The EMBO Journal, 2(4): 571-576.

Ibrahim, M. R.: El-Banna, H. M. and El- Manylawi, M. A. (2010).Evaluating utilization of ground date stone meal with or without kemzyme in the diets of growing New Zealand rabbits. IV International Date Palm Conference, 15-17 March, 2010, Abu Dubi, UAE. Acta Hort. (ISHS), 882:691-697. 
ICMSF, (1980). International commission on microbiology specification of food micro organisms in food. Salmonella. $2^{\text {nd }}$ Ed Univ. Torento press Toronto: 201-201.

Kawahara, E.; Ueda, T. and Nomura, S. (1991).In vitro phagocytic activity of white spotted shark cells after injection with Aermonas salmonicida extracellular products. Gyobokenkyu, Japan 26: 213-214.

Koracevic, D.; Koracevic, G.; Djordjevic, V.; Andrejevic, S. and Cosic, V. (2001). Method for the measurement of antioxidant activity in human fluids. J. Clin. Pathol., 54: 356-361.

Kurtong, D. A. (2014). Performance of weaner rabbits fed maize husk based diets with and without enzyme supplementation. Msc. Thesis, Faculty of Agriculture, Ahmadu Bello University, Zaria

Lopez-Virella, M.F.; Stone, S.; Eills, S. and Collwel, J. A. (1977). Determination of HDL-cholesterol using enzymatic method. Clin. Chem., 23: 882-884.

Masoudi, A.;Chaji M.;Bojarpour, M.and MirzadehKh. (2011). Effects of different levels of date pits on performance, carcass characteristics and blood parameters of broiler chickens, Journal of Applied Animal Research, 39:(4) 399-405.

Mathlouthi, N.;Juin, H. andLarbier, M. (2003).Effect of xylanase and betaglucanase supplementation of wheat- or wheat- and barley-based diets on the performance of male turkeys. British Poultry Science, 44:291-8.

Misra, H. P. and Fridovich, I. (1972).The role of superoxide anion in the autoxidation of epinephrine and a simple assay for superoxide dismutase. Journal. Biol. Chem., 247: 3170-3175.

Mousa, M.R. M. (2013). Growth performance of rabbits fed date pits in north Sinai. Journal Animal and Poultry Production, Mansoura University, 4 (5): $321-333$.

NRC (1977). National Research Councli. Nutrition Requirements Of Domestic Animals. Nutrient Requirements Of Rabbits. $2^{\text {nd }}$ Rev. Ed. National Academy of Science, Washington, D.C.

Paglia, D. E. and Valentine, W. N. (1967). Studies on the quantitative and qualitative characterization of erythrocyte glutathione peroxidase. The Journal of Laboratory and Clinical Medicine, 70(1):158-169.

Rainger, G. E. and Rowley, A. F. (1993).Antibacterial activity in the serum and mucus of rainbow trout, Oncorhyn chusmykiss following immunization with Aeromonas salmonicida. Fish and shellfish Immun., 3: 475-482. 
Reitman, S. and Frankel, S. (1957).A Method for determination of enzymatic activities. American Journal of Clinical Pathology, 287: 56-58.

Ronald, R. Marquardt(2007). Enzyme enhancement of the nutritional value of cears: role of viscous, water soluble, non-starch polysaccharides in chick performance. Department Of Animal Science, University of Manitoba, Winnipeg, MB, Canada.

Saleh, S.Y.; Attia, K.A. andAmal, A.Z. (2006). Effect of multi-enzymes feed additive on performance and some metabolic parameters in turkeys. $\mathrm{Kafr}$ El-Sheikh Veterinary Medical Journal, 4 (1):1307-1319.

Salem, Fayza. M.; El-Alaily, H.A.; El- Medany, N.M. and Abd El-Galil K. (2003).Improving phosphorus utilization in broiler chick diets to minimize phosphorus pollution. Egyptian Poultry Science, 23(11): 201-218.

Sampson, E.J.; Baird, M.A.; Burtis, C.A.; Smith, E.M.; Witte, D.L. and Bayse, D.D. (1980). A coupled-enzyme equilibrium method for the measuring urea in serum: optimization and evaluation of the AACC study group on Urea Candidate reference method. Clinical Chemistry, 26: 816-826.

Sharp, P. J.;Calbert,J. and Wells, J. W. (1987). Variation in stored and plasma Concentrations of androgens and luteinizing hormone during sexual development in the cockerel. Journal Endocrinology, 74: 467 - 476.

Snedecor G.W. and W.G. Cochran (1982). Statistical Methods. $7^{\text {th }}$ Edition, Iowa State University, Press Ames, USA.

Soliman, A. Z. M.;Khidr, R. E.; EL- Manylawi, M. A. F. and El-Sheikh, S. E. M. (2009).Chemical and biological evaluation of date stone meal as an untraditional feedstuff in growing rabbit diets. The 5th International Poultry Conference 10-13 March 2009. Taba- Egypt (852-863).

SPSS (2006).SPSS User's Guide Statistics. Version 10. Copyright SPSS Inc., USA.

Stein, E. A. (1986).Quantitative enzymatic colorimetric determination of total cholesterol in serum or plasma. In: Textbook of Clinical Chemistry. N. W. Tietz, editor. WB. Saunders, Philadelphia, USA Pp. 879-886.

Steven Lukefapor, W.D; Hohenboken, W.D.; Cheeke, P.R.; Patton, N.M. and Kennick, W.H. (1981): Carcass and meat characteristics of Flemish giant and New Zealand white purebred and terminal cross rabbits. Journal of Applied Rabbit Research, 4 (3): 66-72.

Tabook, N.M.;Kadim, I.T.;Mahgoub, O. and Al-Marzooq, W. (2006).The effect of date fibre supplemented with an exogenous enzyme on the performance and meat quality of broiler chickens. British Poultry Science, 47, 73-82. 
EFFECTOFADDINGOF KEMZYMETODIETCONTAININGDATESTONEMEALONRABBITS. 505

Toson, M.; El-Bogdady, A. and Osman, A. (1995).Effect of using date stone meal in rabbit diets. Journal of Agriculture Science, Mansoura University, 20:2160-2169.

Trinder,P. (1969).Enzymatic colorimetric determination ofglucose in serum, plasma or urine. Annals of Clinical Biochemistry, 6: 24-26.

WHO.(2010). World Health Organization.Laboratory Protocol Isolation of Salmonella spp. 5th Ed.From Food and Animal Faeces. WHO Global Foodborne Infections Network (formerly WHO Global Salm-Surv): 118.

Zanu, H.K.;Abangiba, J.;Arthur-Badoo, W.;Akparibo,A.D. and Sam, R. (2012).Laying chickens' response to various levels of palm kernel cake in diets. International Journal of Livestock Production,3(1):12-16.

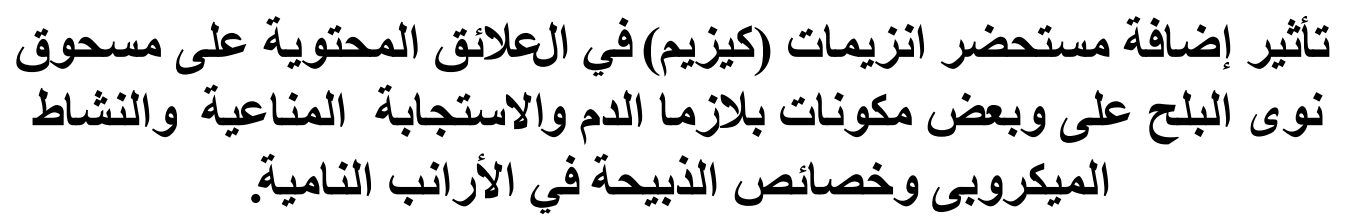

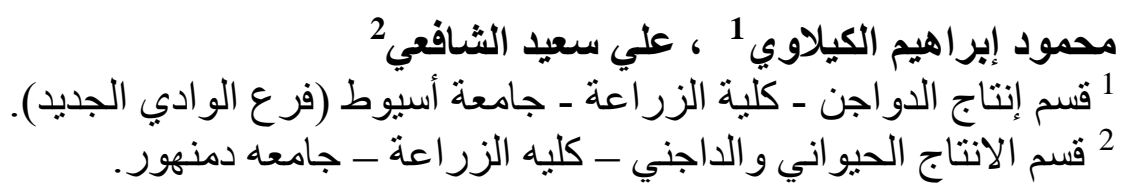

أجريت هذه الدر اسة لتقييم تأثير إضافة مستحضر انزيمات (كيزيم) لعلائق

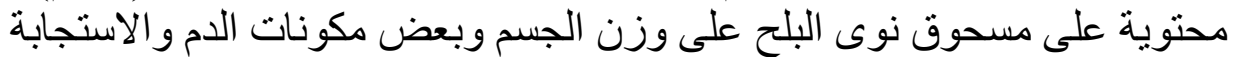

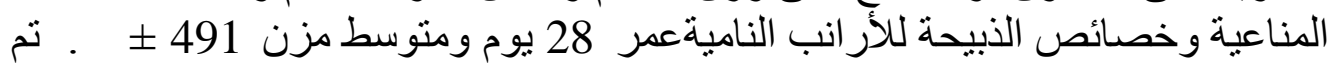

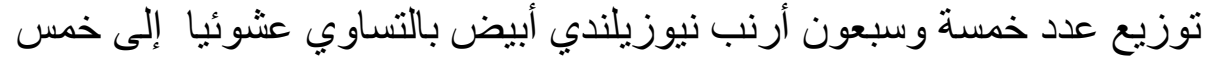

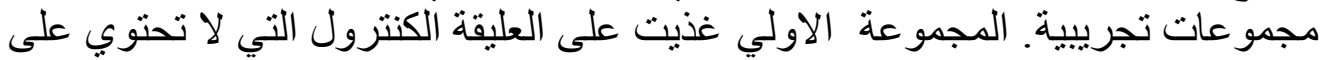

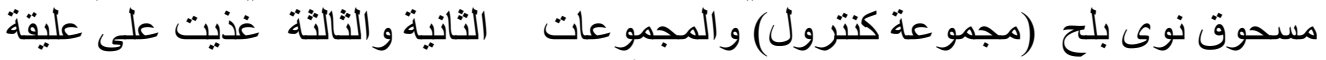
تحتوي على 10\% مسحوق نوى بلح بلدون أو مع إضافة الإنزيمات على على التوالي.

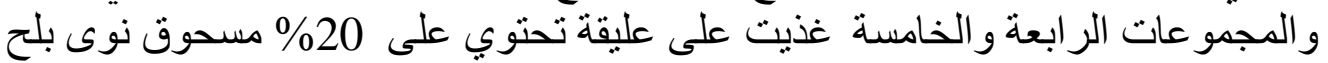

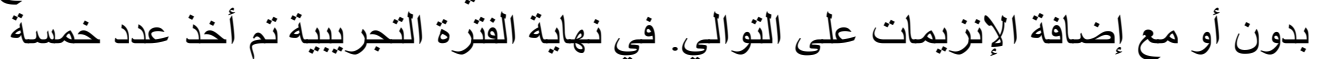

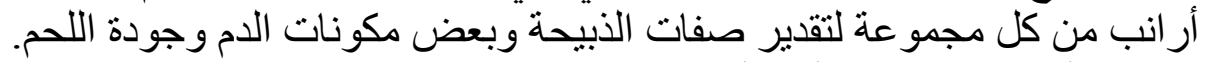
أوضحت النتائج أن الأرانب المغذاه على 10\% 10 مسحوق نوى بلح مع إضافة

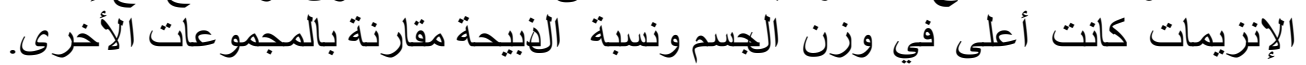


كانت نسبة البروتين و الدهن في لحم الأر انب المغذاه على 10 و 20 \% نوى بلح مع إلع

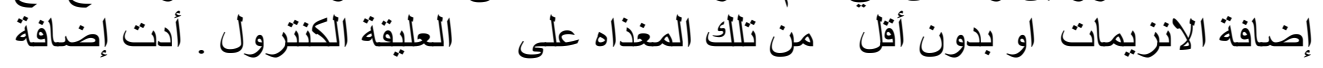

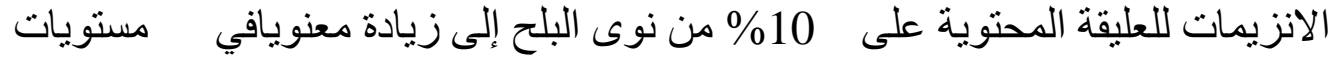

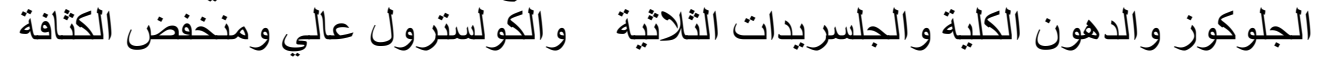

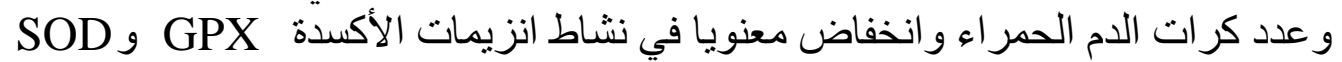

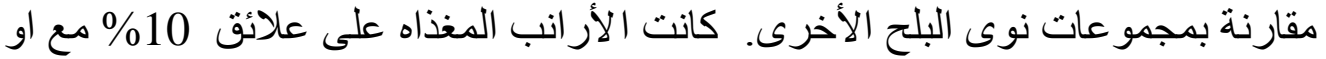

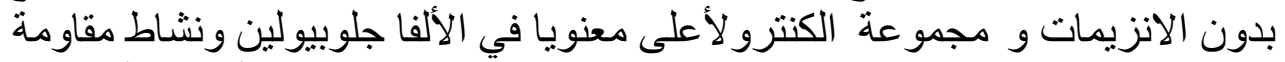

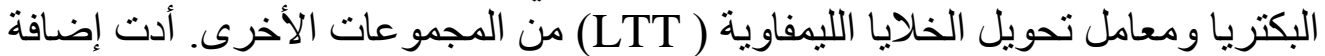

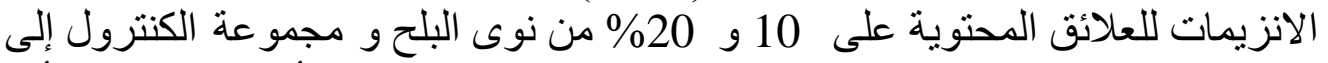

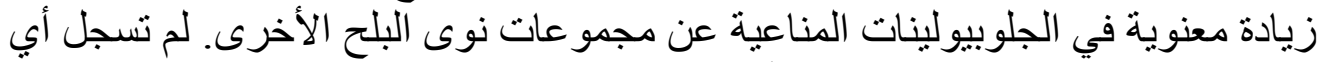

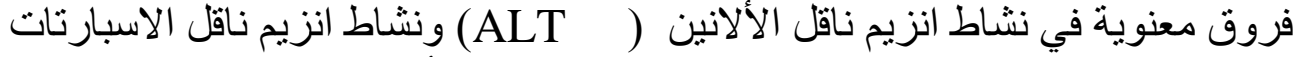

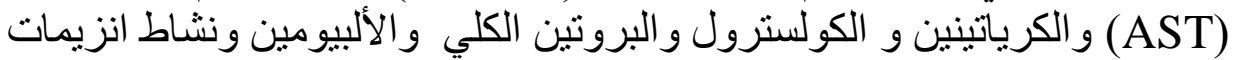

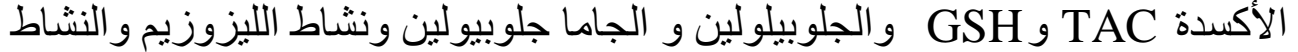

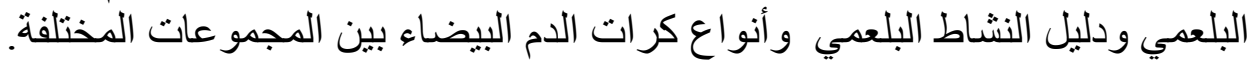

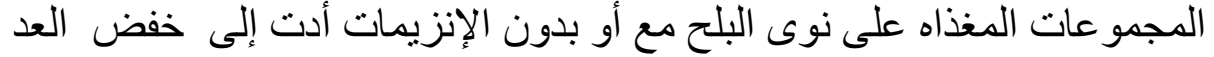

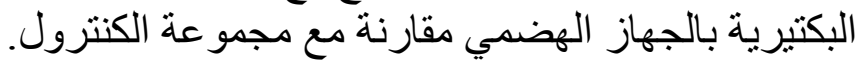

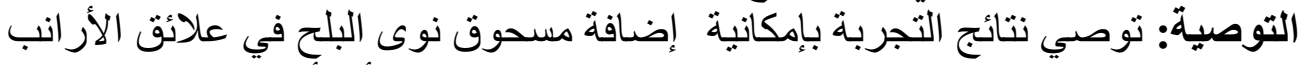

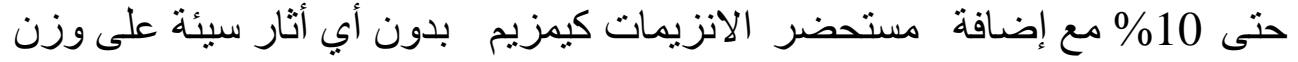
الجسم وصفات الذبيحة ومكونات الذم و الاستجابة الرناعية. 